\title{
3D model of a commercial 9V alkaline battery for EMC simulation
}

\author{
H. Hackl@i, M. Ibel, B. Auinger, D. List, C. Stockreiter
}

The modeling of batteries for simulation is nowadays of increasing importance because their behavior and performance has significant influence on the operation of many modern systems, such as electric vehicles (EV), mobile devices, energy storage and many more. But batteries also play an important role in daily electromagnetic compatibility (EMC) testing and measurement tasks, namely if they are used for powering devices under test (DUT) or measurement equipment. In this paper, we demonstrate the impact of a commercial $9 \mathrm{~V}$ block battery on the result of a bulk current injection (BCI) test when used to supply optical voltage probes attached to the DUT. To illustrate the battery's impact by simulation, a 3D model of selfsame is developed based on its actual internal structure and applying state-of-the-art approaches for battery modeling and commercial 3D EM simulation software. The model is validated by comparison of measurement and simulation of DUT voltages and input current during an actual BCI test.

Keywords: EMC simulation; battery modeling; 3D EM simulation; BCI test ISO 11452-4

\section{D-Modell einer handelsüblichen 9V-Alkaline-Blockbatterie für EMV-Simulationen.}

Durch den zunehmenden Einsatz von Batterien in modernen elektronischen Systemen, wie zum Beispiel in Elektrofahrzeugen und Mobilgeräten, gewinnt auch deren Modellierung für die Charakterisierung, Analyse und Entwicklung der Gesamtsysteme an Bedeutung. Auch im Bereich der elektromagnetischen Verträglichkeit (EMV) haben Batterien eine bedeutende Rolle, insbesondere dann, wenn sie als Versorgung für ein zu testendes System bzw. eine Komponente dienen. In diesem Artikel wird am praktischen Beispiel eines Bulk current injection (BCI)-Tests gemäß ISO 11452-4 demonstriert, wie das Testergebnis durch eine $9 \mathrm{~V}$-Blockbatterie, welche als lokale Versorgung für optische Tastköpfe dient, maßgeblich beeinflusst wird. Um den Effekt mit branchenüblicher Software für elektromagnetische Feldsimulation (ANSYS HFSS) abzubilden, wird unter Berücksichtigung ihrer tatsächlichen internen Struktur und aktueller Literatur ein 3D-Modell der Batterie erstellt. Dieses wird als Ergänzung zu einem bestehenden Simulationsprojekt des kompletten BCl-Aufbaus verwendet.

Schlüsselwörter: EMV-Simulation; Modellierung von Batterien; 3D-EM-Simulation; BCI-Test ISO 11452-4

Received January 23, 2020, accepted February 25, 2020, published online March 16, 2020

(c) The Author(s) 2020

\section{Introduction}

The number and complexity of batteries in modern electric systems is constantly increasing. Consequently, the analysis and simulation of battery performance, dynamics, degradation, thermal and impedance characteristics is a vibrant field of research and scope of many recent publications (mostly considering Lithium-ion types). The generation of battery models has become a fundamental task to enable development and analysis of related electronic systems by simulation. Also in the field of electromagnetic compatibility (EMC) battery modeling is of growing relevance. Accurate depiction of battery's impedance, charge and discharge processes are important for analysis of the electric networks they are part of, e.g. to understand and model conducted emission on attached cable harnesses [1, 2], radiated emission of the same [3] or to precisely predict current ripples produced by power electronic devices switching a batterypowered line [4]. In mentioned works, the battery is replaced with an equivalent circuit model which is a usual approach for network analysis.

Most authors aim to characterize the cell itself and exclude the influence of the battery's housing or measurement fixture, e.g. by de-embedding or analytical correction $[5,6]$. In $[7]$ it is found that neglecting the outer casings of the cells and replacing the cell bodies with perfect electric conductors (PEC) is a suitable approach to speed up 3D simulations of large-scale traction battery systems. [8] is the only work known to the authors where focus is put on respecting the battery housing, although only for frequencies up to $110 \mathrm{MHz}$.

Commonly, battery models are based on measurements of the cell's impedance conducted with an impedance analyzer or vector network analyzer (VNA). Often the focus is on the DC and lowfrequency performance. To the authors' knowledge [5] respects the highest frequency up to now which is $300 \mathrm{MHz}$. In this article, a model valid up to $1 \mathrm{GHz}$ is exhibited.

\subsection{Motivation and application: simulation of bulk current injection $(\mathrm{BCl})$ test}

Bulk current injection ( $\mathrm{BCl}$ ) is a component level test on conducted electromagnetic immunity (EMI) standardized by ISO 11452-4 [9]. It is widely used for testing automotive components. With an injection probe (basically an inductive current transformer) a radio frequency (RF) disturbance current from $100 \mathrm{kHz}-400 \mathrm{MHz}$ is induced to the application-typical cable harness under application-typical load-

Hackl, Herbert, Silicon Austria Labs GmbH, Inffeldgasse 33, 8010 Graz, Österreich (E-mail: herbert.hack|@silicon-austria.com); Ibel, Martin, Silicon Austria Labs GmbH Inffeldgasse 33, 8010 Graz, Österreich; Auinger, Bernhard, Silicon Austria Labs GmbH Inffeldgasse 33, 8010 Graz, Österreich; List, Dominik, ams AG, Tobelbader Straße 30, 8141 Premstätten, Österreich; Stockreiter, Christian, ams AG, Tobelbader Straße 30, 8141 Premstätten, Österreich 


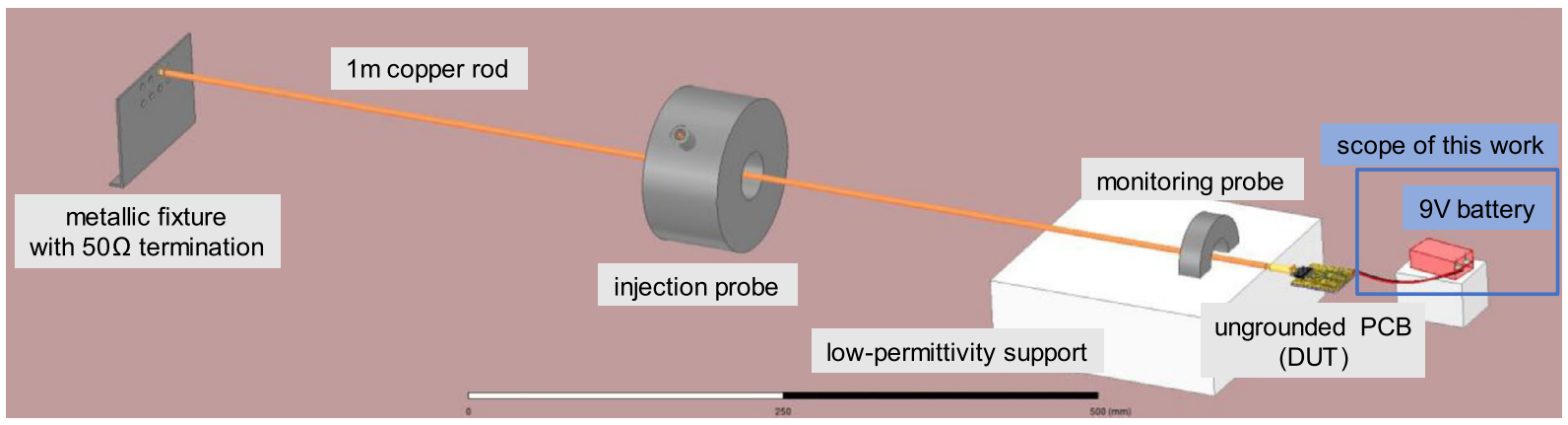

Fig. 1. BCl simulation setup with $1 \mathrm{~m}$ copper rod, ungrounded (floating) PCB and 3D model of 9V battery. (ANSYS HFSS)

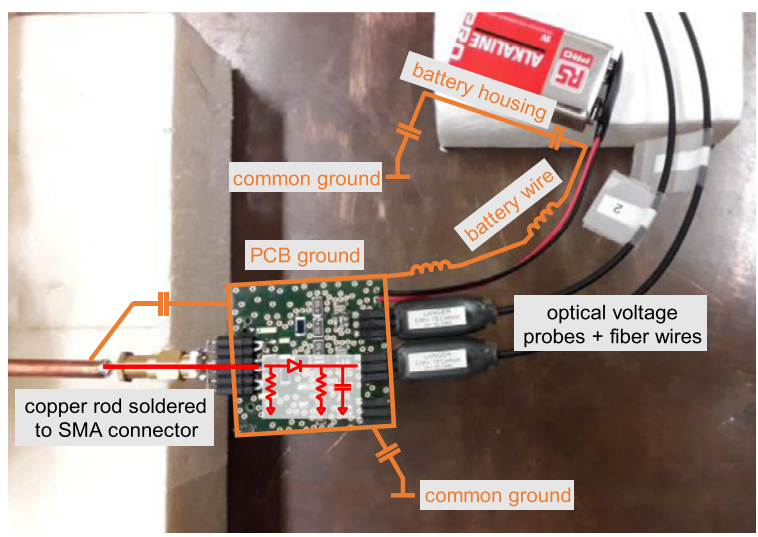

Fig. 2. Photo showing detail of floating PCB connected to copper rod and battery. Coupling paths to the common ground plane are added in orange, including those introduced by the vicinity of the $9 \mathrm{~V}$ battery

ing conditions. At each frequency point the device under test (DUT) is checked for failure. For this work a simplified (academic) version of the setup was used as illustrated by Fig. 1. BCl tests were executed in the EMC lab of the Institute of Electronics at Graz University of Technology, Austria. Instead of a cable harness which typically has many unknown parameters, a well-defined copper rod of $5 \mathrm{~mm}$ diameter and $1 \mathrm{~m}$ length is mounted to a metallic fixture where it is terminated with $50 \Omega$. The injection probe (FCC F-120-6A) is placed at the middle of the rod. A monitoring probe (FCC F-1711171005-1) measures the rod current in $5 \mathrm{~cm}$ distance from the DUT. The latter is an ungrounded PCB equipped with two simple rectifier circuits which generate a $D C$ voltage from the RF input. Figure 2 is a detailed photograph of the DUT. The DC output voltage is measured with optical voltage probes of type Langer AS110. These need a local voltage supply provided by a $9 \mathrm{~V}$ alkaline battery. For brevity, only one of the PCB output voltages is considered throughout this work.

The simulation of $\mathrm{BCl}$ tests and generation of respective models, especially the injection probe, has been scope of many publications and is regarded as state of the art. The models used here were constructed on the basis of [10-12] and related works referenced therein and were thoroughly validated by the authors before. But the simulation of injected current and DUT voltage for the presented setup yielded completely wrong results (compare Fig. 3 and Fig. 4) because the supply battery, hence the additional coupling paths over the battery wire and housing depicted in Fig. 2, were not respected in the original simulation project.

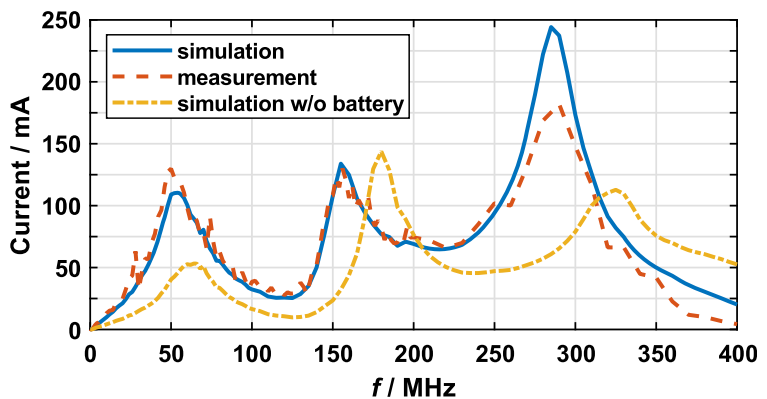

Fig. 3. Measured current in the copper rod during $\mathrm{BCl}$ test in comparison to simulation with and without battery

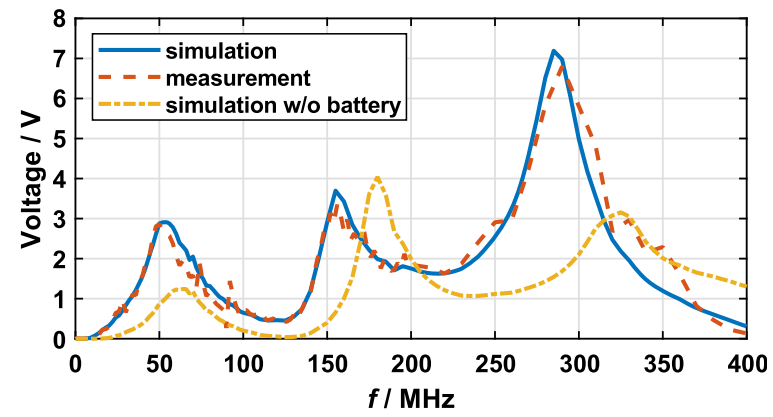

Fig. 4. Measured $D C$ voltage at the rectifier output during $\mathrm{BCl}$ test in comparison to simulation with and without battery

Scope of this work is the development of a battery model used as extension to the existing 3D simulation setup. Advantage of the full 3D simulation (in contrast to battery models based on equivalent circuits) is that the battery can be arbitrarily placed in the $3 D$ setup as in the real environment, thus coupling from the $P C B$, harness, battery wire and ground plane are correctly depicted in simulation. Eventually, this will correct the simulated values as plotted in Fig. 3 and Fig. 4 from the short-dashed to the solid lines. Details on the simulation are given in Sect. 3 .

Models were derived for two commercial $9 \mathrm{~V}$ alkaline block battery (PP3) types of different manufactures, i.e. RS Pro and Panasonic 6LF22, whereas the figures in Sect. 2 account for the latter.

\section{Modeling approach}

The generation of a 3D model requires full knowledge of the battery device. This means in particular its internal buildup and cell material, 


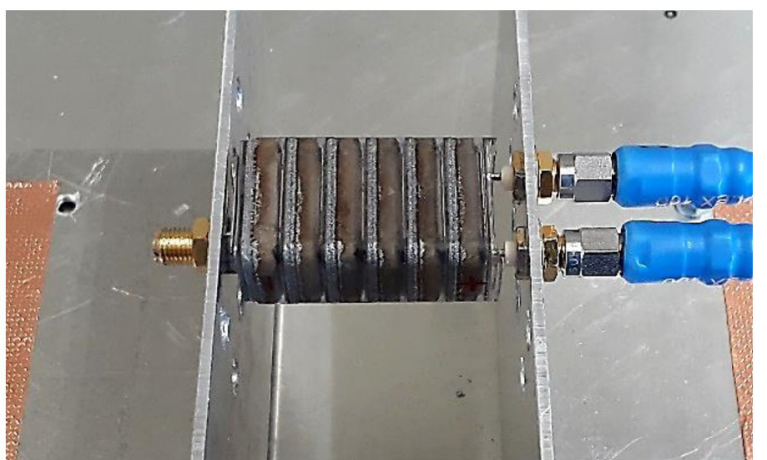

Fig. 5. Impedance measurement of battery cells only with VNA applying shunt-through method of [5]. Both VNA ports are connected to the plus pole, while the minus pole is grounded via the fixture

which are both unknown at the beginning. The model is developed in two stages:

- First, investigation of the cell material,

- Second, composition of the complete battery with housing and such.

The simulation model needs to be built up from the inside to the outside to minimize the number of variable parameters and continuously ensure that all parts of the model reflect real conditions. Consequently, the modeling approach is presented in same order in this work. The detailed interior structure is found by dismantling the battery. This unfortunately makes the modeling a destructive process. Hence, measurements need to be conducted in reverse order (dismantled battery last) to ensure that all measurement data corresponds to a single battery.

\subsection{Measurement and simulation of battery cell block without housing}

The Alkaline cell size and material of course has a major impact on the battery impedance and therefore needs precise modeling. Respecting the cell buildup and material in all detail would result-for the intended application -in a far too complex simulation model (and too high measurement effort). A solution to this problem is to replace the complete cell with an equivalent cell material as presented in [8]. The impedance of the real battery cell is determined by measurement. In simulation, the cell is represented by a simple solid block with an equivalent material which properties are fitted, so that the simulated cell shows the same behavior as the measured one. To determine this equivalent cell material the battery cell needs to be investigated free from all other battery components to exclude as many undetermined impact factors as possible.

\subsubsection{Measurement of cell impedance using VNA shunt-through method}

In [5] the usage of the so-called shunt-through method [13] is proposed to determine a battery's cell impedance (on example of a single Lithium-ion 18650 cell in the referenced work) by its scattering parameters (S-parameters) measured with a VNA. This method is claimed to provide high accuracy for low impedances over a wide frequency range. We used same method but measured the impedance of the complete battery block consisting of 6 seriesconnected cells at once. The measurement setup is shown in Fig. 5. The used test fixture provides SMA coaxial connectors with welldefined reference plane to connect the VNA. The center pins of both

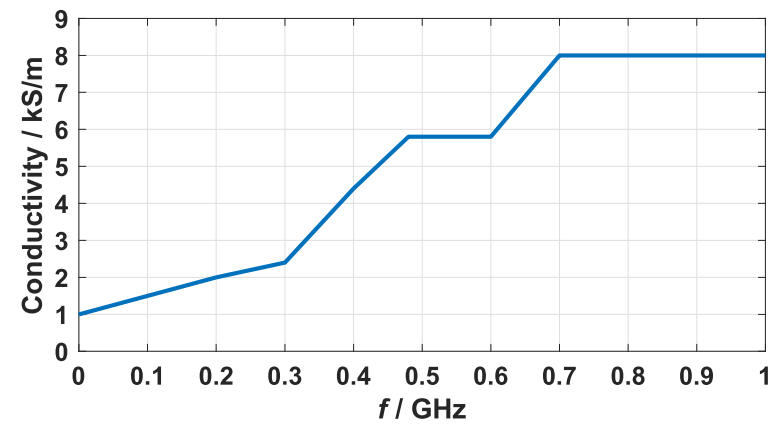

Fig. 6. Conductivity of equivalent cell material

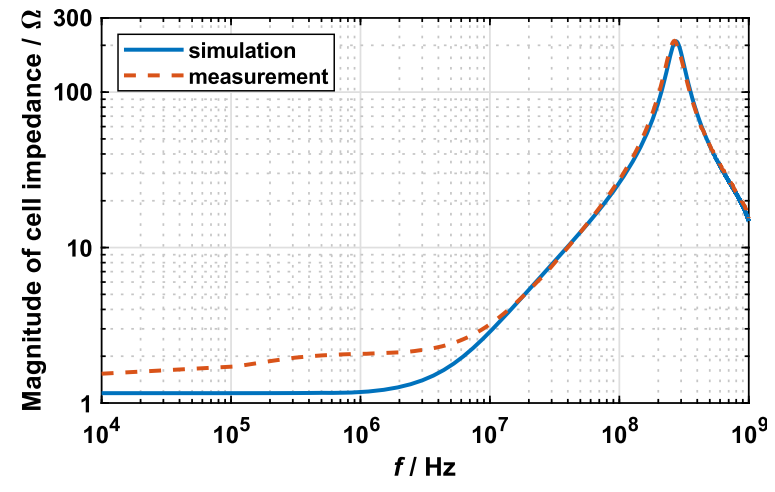

Fig. 7. Comparison of measured and simulated cell impedance $Z_{\text {bat }}$ (test setup of Fig. 5) calculated by (1)

SMA at the right side are soldered to the battery's plus pole and wired to VNA ports 1 and 2. The SMA shields connect to the fixture serving as common ground reference. At the left side, the battery's minus pole connects directly to the fixture, i.e. common ground, via the SMA body. The inputs of the used VNA Copper Mountain S5085 withstand $35 V_{D C}$ hence no DC blocks were needed. Following [5], the battery impedance $Z_{\text {bat }}$ is calculated from the measured transmission coefficient $S_{21}$ by (1), where $Z_{0}$ is the characteristic impedance of $50 \Omega$.

$$
Z_{\text {bat }}=\frac{1}{2} Z_{0} \cdot \frac{S_{21}}{\left(1-S_{21}\right)}
$$

\subsubsection{Simulation of cell impedance by equivalent cell material} Same setup as shown in Fig. 5 was realized with the 3D EM software ANSYS HFSS to gain $Z_{\text {bat }}$ by simulation. For brevity no picture is given at this point, however Fig. 8 already gives a sectional view of the final battery model. For the equivalent cell material, we defined a frequency-dependent conductivity as depicted in Fig. 6 and relative permittivity and permeability of 1 . This is in contrast to [8] where the cells (of NiMH, LiPo and LiFePO4 battery types) were emulated by selecting frequency-constant values for conductivity and permeability. The resulting simulated cell block impedance is compared to the measured values in Fig. 7 for a frequency range of $10 \mathrm{kHz}$ to $1 \mathrm{GHz}$. Besides the cell conductivity, the separation between cells and the area of the aluminum cell-to-cell connections (compare Fig. 8) significantly impacts the resonance around $270 \mathrm{MHz}$.

\subsection{Measurement and simulation of complete battery}

After definition of the series connected battery cells, the complete battery was assembled in simulation as depicted by Fig. 8 and tested 


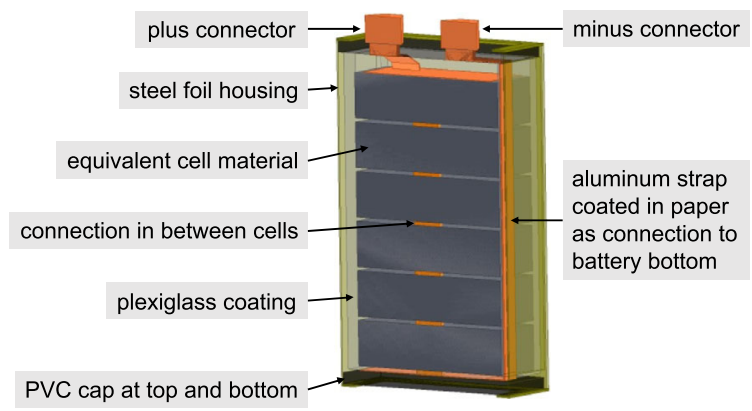

Fig. 8. Sectional view of complete battery 3D model

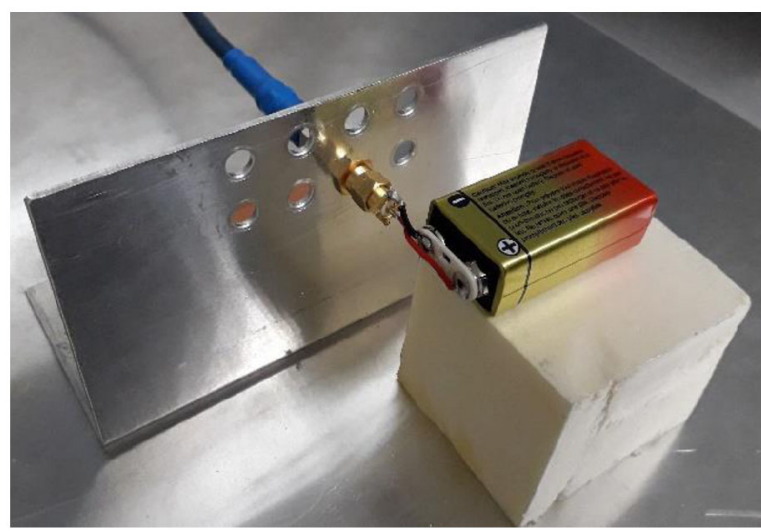

Fig. 9. Battery with wire clip connected to metallic fixture. Measurement of input reflection coefficient $S_{11}$

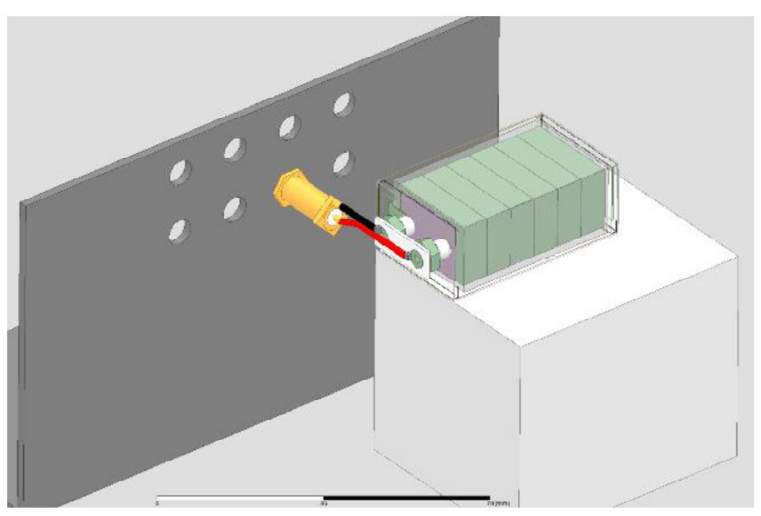

Fig. 10. Simulation setup corresponding to the measurement shown in Fig. 9

against measurement with the setups of Fig. 9 and Fig. 10, respectively. Degrees of freedom in the simulation model which were adjusted in this step are in particular the distance between the aluminum strap (connecting the minus pole at the battery bottom to the plug at the top) to battery cell block and housing, as well as thickness, coating and exact position of the steel foil housing and the geometry of the wire clip connector. Measurements of the input reflection coefficient $S_{11}$ were conducted with two different batteries of same type (Panasonic 6LF22) and are compared to simulation in Fig. 11. The simulation reflects well the general trend over frequency, although the deep resonance at about $530 \mathrm{MHz}$ is underestimated by roughly $7 \mathrm{~dB}$. However, as the main frequency range

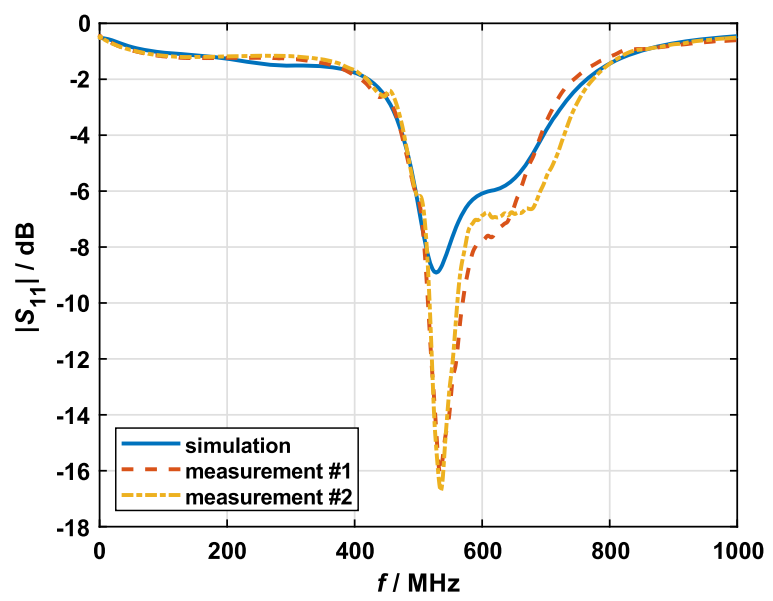

Fig. 11. Magnitude of input reflection coefficient $S_{11}$ for the setups of Fig. 9 and Fig. 10. The simulation is compared to results of two measurements with different batteries of same type

of interest for the $\mathrm{BCl}$ test is only up to $400 \mathrm{MHz}$, this deviation was not further investigated.

\section{Verification: $\mathrm{BCl}$ setup}

The developed battery model was verified by inclusion to the 3D simulation setup of the complete $\mathrm{BCI}$ test as illustrated in Fig. 1. As already mentioned, when the battery is neglected the $\mathrm{BCl}$ test simulation is far from the expected results (compare the dashed lines of Fig. 3 and Fig. 4). Now, the battery's 3D model is added to the simulation project and connected to respective pins on the floating PCB in the illustrated manner, which comes as close as possible to the actual placement visible in Fig. 2. The output from 3D simulation is an 18-port S-parameter matrix exported as Touchstone file. One port is provided for the $\mathrm{BCl}$ probe's connector plus for each (relevant) component footprint on the PCB. Because the PCB circuitry involves an active component, namely the diode of the rectifier circuit, harmonic balance (HB) analysis was used for frequency domain simulation of the complete system. A simplified view of the testbench is Fig. 12. The power input to the $\mathrm{BCl}$ probe was extracted from the measurement protocol provided by the test laboratory and sourced in simulation with a frequency-controlled power source. The optical voltage probes were modeled by differential voltage probes with input impedance of $10 \mathrm{pF}$ parallel to $1 \mathrm{M} \Omega$. During the real $\mathrm{BCl}$ test, the copper rod current was captured in $5 \mathrm{~cm}$ distance from the $\mathrm{PCB}$ with a monitoring probe. For simplicity, this current was assumed to equal the PCB input current in simulation. The final simulation results are given by the solid lines in Fig. 3 and Fig. 4. By respecting the battery's impact, all resonance frequencies and signal amplitudes are correctly shifted to the measured values, but for a deviation of the peak current at roughly $290 \mathrm{MHz}$. 3D simulation of the complete $\mathrm{BCl}$ setup including battery took approximately 4:40h on a laptop PC with Intel 17-7820HQ quad core and 32 GB RAM.

\section{Summary}

Generally, the connection of measurement equipment always influences a device under test. In this work, a drastic case was demonstrated on example of a supply battery for optical voltage probes which noticeably impacted the results of a $\mathrm{BCl}$ test. To depict the battery's impact in simulation, a complete 3D model of selfsame was developed and used as extension to an existing simulation project of 


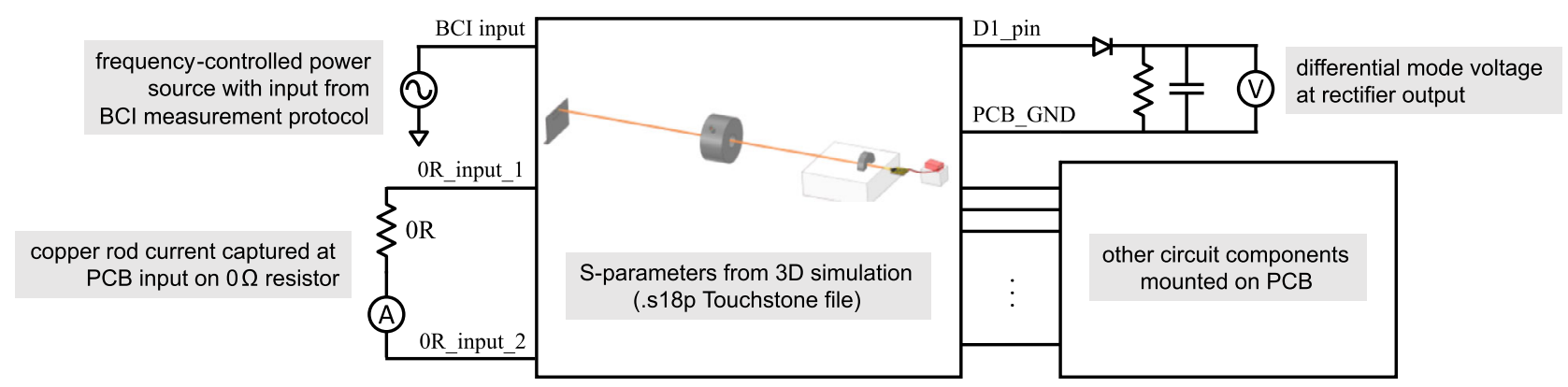

Fig. 12. Simplified view of system level schematic embedding the S-parameter output from the 3D project of Fig. 1. The circuit simulator Keysight ADS was used for HB analysis

the $\mathrm{BCl}$ setup. The specific model generation was detailed in this article. In comparison to other common approaches for battery modeling which often focus only on description of the (transient) behavior of a cell, the proposed model was developed suitable for broadband frequency-domain EMC simulation. The very low frequency impedance and DC point are of less importance, instead parasitic high-frequency resonances due to the package geometry might play a dominant role and are accounted for by detailed consideration of the battery's housing and connection.

The application of proposed model for simulation of the complete $\mathrm{BCl}$ setup results in very close agreement between measured and simulated values. The investigation in simulation additionally shows, that without the parasitic impact of the battery, the DUT's reaction to the induced RF current, hence the $\mathrm{BCl}$ test results, would be very different. This is an important consideration for practical test setups.

Publisher's Note Springer Nature remains neutral with regard to jurisdictional claims in published maps and institutional affiliations.

Open Access Dieser Artikel wird unter der Creative Commons Namensnennung 4.0 International Lizenz veröffentlicht, welche die Nutzung, Vervielfältigung, Bearbeitung, Verbreitung und Wiedergabe in jeglichem Medium und Format erlaubt, sofern Sie den/die ursprünglichen Autor(en) und die Quelle ordnungsgemäß nennen, einen Link zur Creative Commons Lizenz beifügen und angeben, ob Änderungen vorgenommen wurden. Die in diesem Artikel enthaltenen Bilder und sonstiges Drittmaterial unterliegen ebenfalls der genannten Creative Commons Lizenz, sofern sich aus der Abbildungslegende nichts anderes ergibt. Sofern das betreffende Material nicht unter der genannten Creative Commons Lizenz steht und die betreffende Handlung nicht nach gesetzlichen Vorschriften erlaubt ist, ist für die oben aufgeführten Weiterverwendungen des Materials die Einwilligung des jeweiligen Rechteinhabers einzuholen. Weitere Details zur Lizenz entnehmen Sie bitte der Lizenzinformation auf http://creativecommons.org/licenses/by/4.0/deed.de.

\section{References}

1. Reuter, M., Tenbohlen, S., Köhler, W. (2013): Influence of a traction battery's input impedance on conducted emission of an automotive HV inverter. In 2013 international symposium on electromagnetic compatibility (EMC Europe 2013) (pp. 229-234).
2. Jeschke, S., et al. (2017): Development of a passive impedance network for modeling electric vehicle traction batteries for EMI measurements. In 2017 international symposium on electromagnetic compatibility, EMC EUROPE 2017 (pp. 1-6).

3. Kremer, F. Frei, S. (2010): Simulation of emissions of power electronic devices in electrical and hybrid electrical vehicles. In 2010 Asia-Pacific international symposium on electromagnetic compatibility (pp. 691-694).

4. Korth Pereira Ferraz, P., Schmidt, R., Kober, D., Kowal, J. (2018): A high frequency model for predicting the behavior of lithium-ion batteries connected to fast switching power electronics. J. Energy Storage, 18, 40-49.

5. Landinger, T. F., Schwarzberger, G., Jossen, A. (2019): A novel method for high frequency battery impedance measurements. In 2019 IEEE international symposium on Electromagnetic Compatibility, Signal \& Power Integrity (EMC+SIPI) (pp. 106-110).

6. Hoene, E., Guttowski, S., Saikly, R., John, W., Reichl, H. (2003): Rf-properties of automotive traction batteries. In 2003 IEEE international symposium on electromagnetic compatibility. EMC'03 (pp. 425-428).

7. Teo, J. C. Y. X., Ruddle, A. R. (2019): Predicting the RF impedance of cells in parallel for automotive traction battery applications. In 2019 international symposium on electromagnetic compatibility, EMC EUROPE (pp. 438-443).

8. Raya, M., Vick, R. (2017): A simulation method to determine the RF impedance of batteries. In 2017 international symposium on electromagnetic compatibility, EMC EUROPE (pp. 1-5).

9. ISO 11452-4:2011(E) (2011): Road vehicles-Component test methods for electrical disturbances from narrowband radiated electromagnetic energy—Part 4: Harness excitation methods. Geneva, $\mathrm{CH}$ : International Organization for Standardization.

10. Toscani, N., Grassi, F., Spadacini, G., Pignari, S. A. (2018): Circuit and electromagnetic modeling of bulk current injection test setups involving complex wiring harnesses. IEEE Trans. Electromagn. Compat., 60(6), 1752-1760.

11. Grassi, F., Marliani, F., Pignari, S. A. (2007): Circuit modeling of injection probes for bulk current injection. IEEE Trans. Electromagn. Compat., 49(3), 563-576.

12. Miropolsky, S., Frei, S., Frensch, J. (2010): Modeling of bulk current injection (BCI) setups for virtual automotive IC tests. In Proc. EMC Europe 2010 (pp. 123-128).

13. Keysight Technologies (March 2018): Performing Impedance Analysis with the E5061B ENA Vector Network Analyzer. Application Note 5991-0213EN. 


\section{Authors}

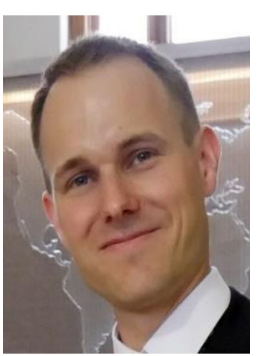

\section{Herbert Hack}

received the B.Sc., M.Sc. and Ph.D. degrees in electrical engineering from Graz University of Technology, Austria, in 2012, 2014 and 2019, respectively. From 2014 to 2018 he worked on the simulation of radiated emission of integrated circuits at NXP Semiconductors Austria in cooperation with the Institute of Electronics of Graz University of Technology. Currently, he is employed as scientist at Silicon Austria Labs (SAL) in Graz, Austria, where his field of research includes the simulation of electromagnetic compatibility and coexistence (EMCC) with focus on model-based design of electronic circuits and systems

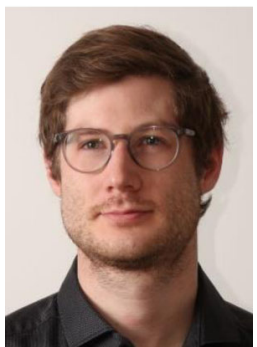

\section{Martin Ibel}

received the B.Sc. degree in electrical engineering from Graz University of Technology (TU Graz), Austria, in 2016. In his bachelor thesis he worked on speech communication at the Institute of Signal Processing and Speech Communication. He is currently pursuing the M.Sc. degree in electronic systems at the Institute of Electronics at TU Graz. In his master thesis he is working on modeling of a standardized automotive EMC test. From 2017 to 2018, he was a student assistant with the Institute of Electric Drives and Machines, TU Graz. Since 2018, he is a research assistant at Silicon Austria Labs, in the department for electromagnetic compatibility and coexistence (EMCC).

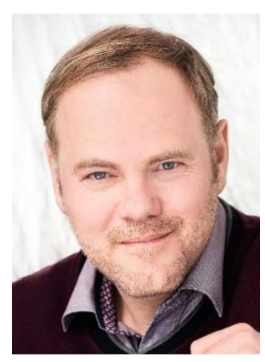

\section{Bernhard Auinger}

received the master's degree in electrical engineering (Dipl.-Ing.) in 2004 and the Dr. techn. degree with distinction in 2015, both from Graz University of Technology, Austria. Between 2015 and 2018 he was in Electromagnetic Compatibility for power electronics and the pre-estimation of EMC. From 2011 to 2015 he was involved in theoretical investigations for wireless communications test procedures of LTE handsets using MIMO, which was a cooperation between the Institute of Microwave and Photonic Engineering, Graz University of Technology and the company Rohde \& Schwarz, Munich, Germany. From 2005 to 2011 he initiated and led the electromagnetic compatibility group for automotive ICS at Philips Semiconductors and NXP Semiconductors. During his studies he was engaged in the comet mission ROMAP/ROSETTA of the European Space Agency (ESA). Currently, he is leading the EMC department at Silicon Austria Labs in Graz, Austria, where he aims for a paradigm shift in electronics design by enabling simulation of electromagnetic compatibility of electronic based systems.

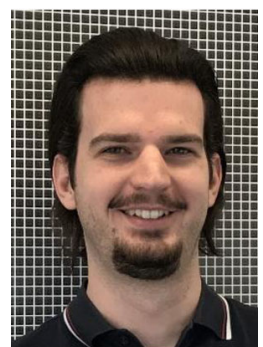

\section{Dominik List}

is with ams AG since 2007, where he finished his apprenticeship training in 2011 as Electronics Technician with focus on applied electronics. During this time, he was working as Evaluation Engineer in the field of integrated magnetic position sensing. In 2011, he switched within the company to the High Voltage department responsible for the development of evaluation software as well as hardware and the execution of the test plan. Since 2015, he is part of the corporate ESD\&EMC team as an EMC Engineer where he is supporting project teams to fulfill the requirements for electromagnetic emission and immunity. Part of his responsibilities is to develop and implement standardized measurement environment with individually suited software and hardware solutions. In parallel, he is pursuing his bachelor's degree in Automation Technology at the University of Applied Sciences campus02 in Graz.

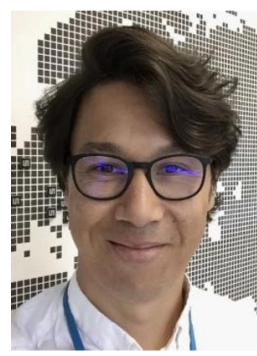

Christian Stockreiter

received the master's degree and the Ph.D. degree in electrical engineering from Graz University of Technology, Austria, in 2004 and 2009, respectively. From 2004 to 2005, he worked as a Research Assistant at the Institute for Fundamentals and Theory in Electrical Engineering (IGTE) at TU Graz. In 2006, he joined the Systems and Analog Innovation team of NXP Semiconductors Austria and worked as RF System Engineer focusing on the design of $\mathrm{HF}$ and UHF RFID systems. In 2008, he started a new assignment as Design Manager at Magna Steyr Fahrzeugtechnik in Graz, where he was responsible for the development of automotive antenna systems. Since 2010, he is with the corporate R\&D organization of ams $A G$ and is now leading the corporate validation R\&D department with the functional areas validation methodologies, ESD\&EMC and the corporate R\&D laboratories. His current research interests are numerical simulation of electromagnetic fields, circuit simulation, EMC of integrated circuits and systems and RF measurement techniques. 